\title{
DETERMINANT OF IN-APP MOBILE GAME PURCHASE INTENTION: AN EMPIRICAL STUDY OF INDONESIAN MOBILE GAMER
}

\author{
Benediktus Andjar Tito Atmoko ${ }^{1}$, Jeanne Ellyawati ${ }^{2}$ \\ \{andjar.atmoko@gmail.com, j.ellyawati@uajy.ac.id\} \\ Master of Management, Universitas Atma Jaya Yogyakarta, Indonesia ${ }^{1,2}$ \\ Jl. Babarsari No. 43. Yogyakarta, Indonesia
}

\begin{abstract}
Games have become an interesting business and even in a pandemic COVID-19 situation like today, most businesses are collapse, but mobile games still become promising market segments. This study aims to examine factors that determine the purchase intention of in-app mobile games for non-paying players to target the young gamers market in Indonesia. Several 264 mobile gamers were recruited as respondents. Data were collected using a cross-sectional survey with a structured questionnaire. SmartPLS was used to verify the research hypotheses. Based on the study result, reward affects the good price, and affect in-app purchase intention. Playfulness, access flexibility, connectedness, and reward did not affect in-app purchase intention. This shows that gamer intends to buy if the price is good, and this is supported by the availability of reward. Therefore, companies still have to work hard to explore more deeply the variables studied why these variables do not support purchase intentions.
\end{abstract}

Keywords: in-app mobile game, emotional value, quality value, social value, purchase intention.

\section{Introduction}

Besides having a big impact on mobile phone development, technology also has a big impact on the development of the gaming world. In 2019, the value of the global gaming market will reach USD152 billion, an increase of 9.6 percent over the previous [1]. Research in Indonesia shows [2] that from 518 samples studied, all of them claimed that they spent their free time playing games even though not all of their samples had smartphones, and five percent of the samples studied have made purchases in gaming applications.

The Mobile Legend Bang Bang (MLBB) game is the most popular game on mobile devices. In Indonesia, MLBB has 31 million active monthly users, and even this game is officially used for the 2019 SEA Games [3]. There are currently 42.9 million gamers in Indonesia, whereas, in 2015, there was only half of that number. In the next five years, according to the DANA estimation, the number of gamers will increase threefold [4]. Internet penetration rates in Indonesia in 2019 increased by 10\% from 2018. While the comparison between the number of internet users in Indonesia and the number of gamers is also likely to increase considering that new generations will have been exposed to the technology virus.

The mobile game may be downloaded for free, but for the game to be more interesting, a gamer can buy various virtual products in the game. This is of course a very promising market opportunity for mobile game companies. The problem is how marketing managers can take advantage of this opportunity to achieve success. Many factors influence users' in-app mobile game purchasing behavior. Previous research stated that good price and customer loyalty are recognized as the main determinants of intention to pay [5]. In his research, [6] shows that the perceived value of having internet facilities on a mobile device affects the intention of 
smartphone users to pay for mobile phone services. This study adopts a previous research model conducted by [5] and is adapted to the needs of the study.

\section{Literature Review}

\section{Virtual item}

Virtual items are virtual products or non-physical products that are sold and played in online gaming communities. Items that are purchased or shipped through the virtual world are virtual properties. Virtual items in online games can be custom avatars, bases, or player characters that are purchased using real money [7].

\section{Emotional Value}

Emotional value is a person's perception of the benefits obtained from the use of a product [8]. Emotional value arises as a result of trying something new or something different [9]. Based on previous research, it was found that people will be more affected to attend a festival because of emotional (hedonic) values obtained from the playfulness of the festival [10]. Another study found that customer perceived emotional value tends to influence customer intention to buy local products and international products [9]. Based on these arguments, the hypothesis proposed is:

H1. Perceived playfulness effect positively on in-app purchase intention.

\section{Performance/Quality Value}

The performance or quality value is defined as the value or benefit perceived by users about the quality or performance of services in the mobile game used [5]. In their study, performance or value quality is measured using variable access flexibility. What is meant by access flexibility is the user's flexibility in controlling time when playing games. Meanwhile, another study found that access flexibility and time flexibility influence users' intention to use the game [11].

$\mathrm{H} 2$. Access flexibility affects positively on in-app purchase intention.

\section{Social Value}

Social value can be interpreted as the value obtained by the user as a result of social interactions that occur between that user and other users through experience in using that service [12]. Social interaction causes users to feel attached, have feelings of closeness and connectedness. Connectedness is a user's feeling of being connected to other users [13]. When connectedness arises between a player and other players in the game, then there is a tendency of the user to make in-app purchase intention [5].

H3. Connectedness effect positively on in-app purchase intention.

\section{Value for Money (Good Price and Reward)}

In buying a product, a fair price is often the main consideration in making a decision. In high competition, a fair price can be the main key to the success of the product in the market. Fair prices can be defined as a combination of product and service quality [14]. Thus the price of a product is said to be expensive or cheap depending on the quality of the product. Price reward is a consumer's perception of product quality that is by the price offered by the company. Previous studies stated that value for money is the value that arises as a result of the reduction in costs that are the long-term or short term of a product [8]. The past empirical study stated that value for money drives potential customers to intend to make a purchase [15]. Besides, in the same study, it was found that connectedness that occurs among users, positively affects the user's perception of a good price. The higher the connectedness, the more users feel the price is fairer.

H4. Good price effects positively on in-app purchase intention

H5: Connectedness effects positively on good price

Value for money is also measured by the size of the reward given by the company. The higher the reward is given by a company, the greater the value for money perceived by the user. Reward is several benefits felt by users when playing games [5]. The result of their study stated that reward affects a person's perception of fair prices. The greater the reward is given by a company, the better the price on the eyes of users. Furthermore, it was found that reward has a positive effect on in-app purchase intention. 
H6. Reward effect positively on in-app purchase intention.

H7. Reward effect positively on good price.

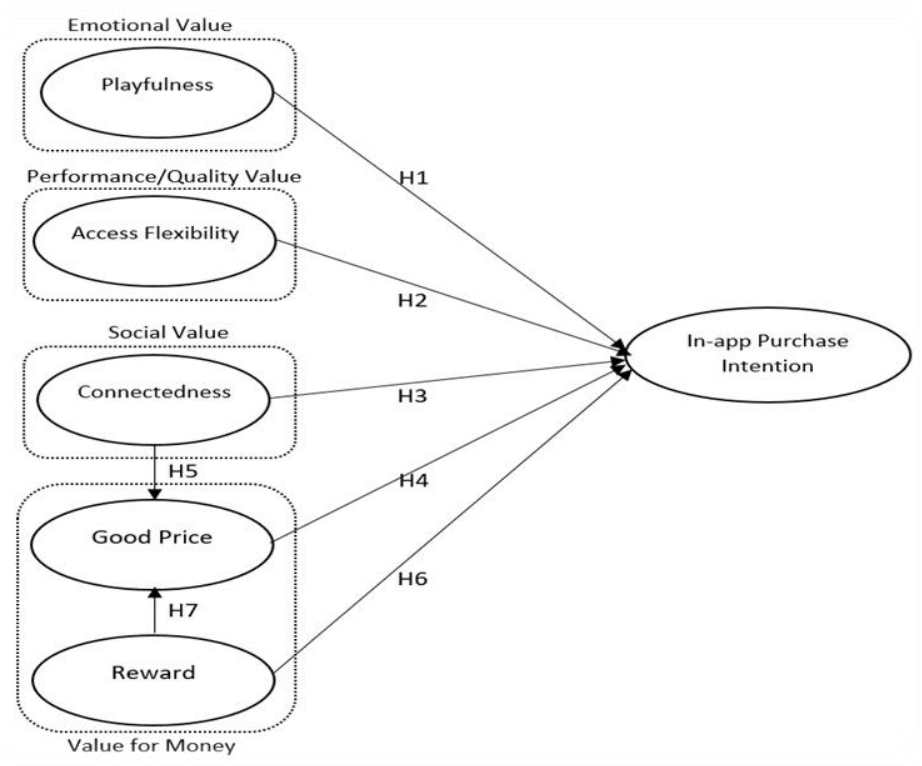

Fig 1. Research Model

\section{Research Method and Data Analysis}

\section{Sample and Data Collection}

The research instrument was adopted from previous studies [5] and adapted to the needs of the study. After being translated into Bahasa, and tested on several respondents for face validity, a pilot test was then carried out by distributing the research questionnaire to 30 respondents. Data were tested with validity and reliability using SPSS. After all the data were stated valid and reliable, the questionnaire was distributed to targeted respondents.

A cross-sectional online survey design is employed through google form in November 2019. Every respondent was asked to fill the administered questionnaire. To avoid ambiguous answers, an itemized rating scale with an unbalance rating scale is used to measure the research instrument, which is from score 1 to score 4 [16]. This study uses a purposive sampling method and data was analyzed with SEM-PLS statistical program. Respondents who may fill out the questionnaire are gamers who have playing MLBB games in the last six months.

\section{Reliability, Convergent Validity, and Discriminant Validity}

There are two measurement models in SEM-PLS analysis, namely the measurement model (outer model) and the structural model (inner model). The outer model is used to test construct validity and instrument reliability which can be seen through Cronbach's alpha and composite reliability (internal reliability consistency), outer loading and AVE (convergent validity), crossloading, and The Fornell-Larcker criterion (discriminant validity). Evaluation of the inner model is tested from the value of path coefficients (ß), coefficient of determination (value of $\mathrm{R}^{2}$ ), size of the effect (value of $\mathrm{f}^{2}$ ), the relevance of the prediction (value of Stone-Geisser's $\mathrm{Q}^{2}$ ), and significant pathway ( $\mathrm{p}$-value).

Based on the results of the outer model, all research items of the instrument are stated reliable and valid, therefore data can be tested with the structural equation model. The value of $\mathrm{R}^{2}$ of good price is 0.111220 . This means that simultaneously connectedness and reward as an independent variable can explain $11.122 \%$ changes in good price as the dependent variable. inapp purchase intention has an $\mathrm{R}^{2}$ value of 0.460061 . It can be concluded that the variables of playfulness, access flexibility, good price, reward, and connectedness simultaneously can explain $46 \%$ of changes in in-app purchase intention.

The reliability of the instrument can be seen from the consistency of internal reliability assessed by Cronbach's alpha and composite reliability [17]. Table 1 presents the results of 
Cronbach's alpha test and composite reliability of the measurement model. Based on the PLS output result, the value of Cronbach's alpha for all observed variables exceeds 0.7 with values ranging from 0.825407 to 0.948358 . This can be interpreted that all observed variables have high internal consistency.

Table 1. Validity and Reliability Test Result

\begin{tabular}{|c|c|c|c|c|c|}
\hline \multirow{2}{*}{ Variable } & \multirow{2}{*}{$\begin{array}{l}\text { Indicator } \\
\text { code }\end{array}$} & \multicolumn{2}{|c|}{ Convergent validity } & \multicolumn{2}{|c|}{$\begin{array}{c}\text { Internal consistency } \\
\text { reliability }\end{array}$} \\
\hline & & $\begin{array}{c}\text { Outer } \\
\text { loadings }\end{array}$ & AVE & $\begin{array}{c}\text { Cronbach's } \\
\text { alpha }\end{array}$ & $\begin{array}{l}\text { Composite } \\
\text { reliability }\end{array}$ \\
\hline Playfulness [13] & & & 0.858881 & 0.948358 & 0.960487 \\
\hline I think playing MLBB is interesting. & PLA1 & 0.8659 & & & \\
\hline I think playing MLBB is enjoyable. & PLA2 & 0.9427 & & & \\
\hline I think playing MLBB is exciting. & PLA3 & 0.9607 & & & \\
\hline I think playing MLBB is fun. & PLA4 & 0.9348 & & & \\
\hline Connectedness [13] & & & 0.858367 & 0.920718 & 0.947785 \\
\hline $\begin{array}{l}\text { Players of MLBB share their experience } \\
\text { and feelings with others through this } \\
\text { mobile game. }\end{array}$ & CON1 & 0.9524 & & & \\
\hline $\begin{array}{l}\text { Players of MLBB benefit from the user } \\
\text { community using this mobile game. }\end{array}$ & $\mathrm{CON} 2$ & 0.9523 & & & \\
\hline $\begin{array}{l}\text { Players of MLBB share a common bond } \\
\text { with other players. }\end{array}$ & CON3 & 0.8724 & & & \\
\hline Access flexibility [11] & & & 0.819363 & 0.891653 & 0.931497 \\
\hline $\begin{array}{l}\text { I can control the time playing MLBB by } \\
\text { myself. }\end{array}$ & $\mathrm{ACC} 1$ & $0 . .8758$ & & & \\
\hline I can play MLBB anytime. & ACC2 & 0.9358 & & & \\
\hline $\begin{array}{l}\text { I can begin and stop playing MLBB at } \\
\text { any time. }\end{array}$ & ACC3 & 0.9030 & & & \\
\hline Good price [6] & & & 0.801551 & 0.875435 & 0.923650 \\
\hline $\begin{array}{l}\text { Diamonds of MLBB are reasonably } \\
\text { priced. }\end{array}$ & PRI1 & 0.9247 & & & \\
\hline $\begin{array}{l}\text { Diamonds of MLBB are good relative to } \\
\text { the price. }\end{array}$ & PRI2 & 0.8438 & & & \\
\hline Diamonds of MLBB are economical. & PRI3 & 0.9152 & & & \\
\hline Reward [18] & & & 0.865518 & 0.922355 & 0.950755 \\
\hline $\begin{array}{l}\text { The proposed rewards have high cash } \\
\text { value. }\end{array}$ & REW1 & 0.9355 & & & \\
\hline $\begin{array}{l}\text { It is highly likely to get the proposed } \\
\text { rewards. }\end{array}$ & REW2 & 0.9363 & & & \\
\hline $\begin{array}{l}\text { The proposed rewards are what I have } \\
\text { wanted. }\end{array}$ & REW3 & 0.9193 & & & \\
\hline In-app purchase intention [6] & & & 0.910777 & 0.902095 & 0.953305 \\
\hline $\begin{array}{l}\text { I intend to pay for the diamonds in } \\
\text { MLBB in future. }\end{array}$ & IAP1 & 0.9521 & & & \\
\hline $\begin{array}{l}\text { I predict that I would pay for the } \\
\text { diamonds in MLBB in future. }\end{array}$ & IAP2 & 0.9566 & & & \\
\hline
\end{tabular}

Table 1 shows the results of the average variance extracted (AVE) for all observed variables exceed 0.5. According to [17], AVE value exceeds 0.5 is a measurement standard which shows that on average the variables explain more than half of the indicator variants. The value of outer loadings for each indicator in this study is higher than 0.7 .

Discriminant validity is the extent to which a variable is completely different from other variables [17]. The value of outer loadings of indicators for related variables must be higher than the outer loadings of other variables, and the value of outer loadings of indicators for each variable must exceed 0.7 [17]. Table 2 shows that the value of the outer loadings of each indicator is greater than all outer loadings of the other variables. 
Table 2. Cross Loading

\begin{tabular}{|l|l|l|l|l|l|l|}
\hline & ACC & CON & IAP & PLA & PRI & REW \\
\hline ACC1 & 0.875779 & 0.563575 & 0.289577 & 0.533271 & 0.323724 & 0.442033 \\
\hline ACC2 & 0.935777 & 0.450694 & 0.416602 & 0.411026 & 0.399419 & 0.487642 \\
\hline ACC3 & 0.903008 & 0.409805 & 0.272203 & 0.345545 & 0.364790 & 0.401217 \\
\hline CON1 & 0.483945 & 0.952360 & 0.215493 & 0.754024 & 0.240574 & 0.573450 \\
\hline CON2 & 0.488789 & 0.952309 & 0.153332 & 0.744682 & 0.187271 & 0.569029 \\
\hline CON3 & 0.485540 & 0.872478 & 0.108723 & 0.725688 & 0.124669 & 0.525869 \\
\hline IAP1 & 0.328093 & 0.160206 & 0.952053 & 0.126654 & 0.618396 & 0.272038 \\
\hline IAP2 & 0.382166 & 0.187910 & 0.956635 & 0.162127 & 0.644077 & 0.279518 \\
\hline PLA1 & 0.408120 & 0.759809 & 0.044642 & 0.865889 & 0.053536 & 0.501537 \\
\hline PLA2 & 0.444697 & 0.719674 & 0.152500 & 0.942674 & 0.121202 & 0.527909 \\
\hline PLA3 & 0.456284 & 0.767454 & 0.138840 & 0.960740 & 0.118313 & 0.545376 \\
\hline PLA4 & 0.439238 & 0.753918 & 0.162738 & 0.934936 & 0.168853 & 0.553344 \\
\hline PRI1 & 0.394622 & 0.194733 & 0.613608 & 0.104067 & 0.924729 & 0.264864 \\
\hline PRI2 & 0.283764 & 0.272422 & 0.525315 & 0.244236 & 0.843766 & 0.332350 \\
\hline PRI3 & 0.400825 & 0.108502 & 0.633286 & 0.036547 & 0.915199 & 0.300960 \\
\hline REW1 & 0.452552 & 0.583416 & 0.265863 & 0.524934 & 0.289567 & 0.935460 \\
\hline REW2 & 0.462694 & 0.571335 & 0.263477 & 0.564089 & 0.306107 & 0.936337 \\
\hline REW3 & 0.465805 & 0.524270 & 0.276493 & 0.513946 & 0.331994 & 0.919098 \\
\hline
\end{tabular}

\section{Research Result and Discussion}

\section{Respondent Profile}

Several 264 samples were collected. Data were then analyzed using the SEM-PLS statistical program. Based on data collected, the majority of players are male (87.2\%), aged between 17 to 22 years $(70.3 \%)$. They have an average experience playing the game Mobile Legends between six months to twelve months $(53 \%)$. The most widely used mobile game platform is android (79.7\%). The length of time spent playing MLBB between 1-3 hours (63.9\%) per day.

\section{Hypothesis Testing}

The hypothesis will be supported if the path has a t-statistic value greater than the t-table $(\alpha=0.05)$. For data of $264(\infty)$ and $\alpha=0.05$, the value of $t$-table $=1.96$ (Hair et al., 2014). Based on the result shows that $\mathrm{H} 1(\mathrm{t}=0.039389), \mathrm{H} 2(\mathrm{t}=1.009435), \mathrm{H} 3(\mathrm{t}=0.742170), \mathrm{H} 5=(\mathrm{t}=0.123653)$, and $\mathrm{H} 6(\mathrm{t}=0.143314)$ are rejected. While $\mathrm{H} 4(\mathrm{t}=4.435841), \mathrm{H} 7(\mathrm{t}=3.008566)$, are supported. These mean that playfulness, accessibility, reward, connectedness do not affect in-app mobile games intention.

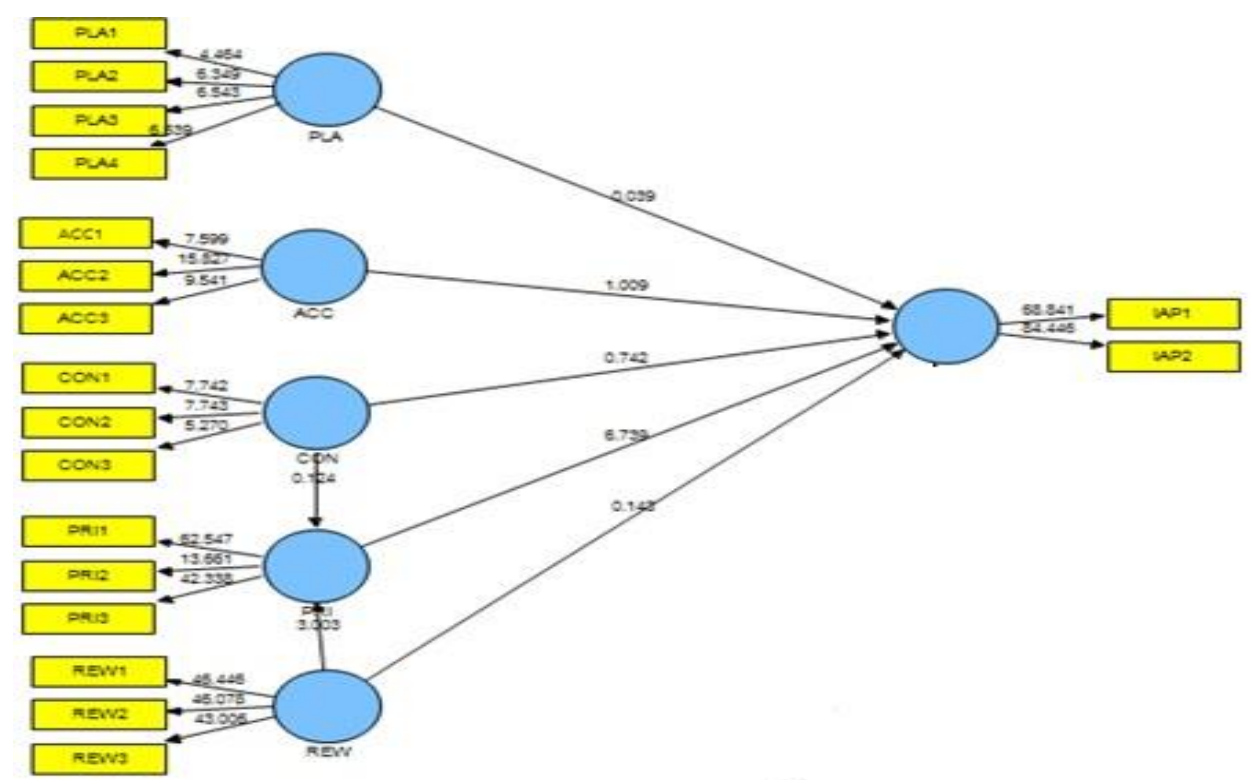

Fig 2. The Structural Model Test Result 
Good price effects positively and significantly on in-app purchase intention $(\beta=0.597$; $\mathrm{t}$ stat>1.96), H4 is supported. This study indicates that the more appropriate the price offered in the game will increase in-app purchase intention. Reward influence positively and significantly on good price $(\beta=0.324$; $\mathrm{t}$-stat>1.96), $\mathrm{H} 7$ is supported. The results of this study indicate that the higher the level of reward available in the game will increase gamer perception of a good price. playfullnes, accessibility, connectedness, and reward do not affect in-app purchase intention. The only variable that directly influences on in-app purchase intention of mobile games is good price, and it has the biggest $\beta$-value. Good price has proven to be the main key for marketers to increase in-app purchase intention. Partially the independent variables do not significantly influence on in-app purchase intention variable, but simultaneously palyfullness, accessibility, good price, reward, and connectedness influence intention of in-ap purchases by 46 percent $\left(\mathrm{R}^{2}=0.460061\right)$.

This study found that connectedness does not affect the player perception of good price. The experience of playing games with friends, the benefits gained, and attachment to other players does not affect the perception of good price. This study is in line with a study conducted by [5]. It stated that connectedness did not have a significant effect on good price for respondents who have never had experience buying in a game application. However, reward affects the perception of good price $\left(\mathrm{R}^{2}=0.111220\right)$. This means that simultaneously, connectedness and reward can explain good price of 11.12 percent. This value is very small, so indeed the effect is very low. This finding is in line with the results of previous research conducted by [5]. Reward in in-app mobile games is expected by gamers to be able to save funds and to play longer. The higher the reward, the better the perception of the price offered.

\section{Implications, Limitations and Suggestions for Further Research}

This study result indicates that all observed variables such as pleasure in playing games, ease of players in accessing the game, the connectedness of players with other players, and reward are given do not influence on in-app purchase intention. This study found that good price effect on in-app purchase intention. This might be related to the majority of respondents who are teenagers and still in school. They may not prioritize buying virtual items in the game, but their expenses are mostly used for school needs. Therefore, gamers will only buy virtual items which are a good price.

The study results found that reward has an effect on a good price. To attract gamers to intend to pay for virtual items, a marketing manager should focus on increasing the perceived value of mobile game services through a bonus, the package offers, or promotions. Consumer makes a buying decision based on a good price given by the game. The reward given by the game to players for free will affect player perception of the price offered.

For further research demographics, characteristics such as education, employment, and income levels need to be added so that a more detailed profile of gamers will be obtained for the benefit of consumer segmentation. In this study, respondents were not differentiated between paying and non-paying players for in-app mobile games. The fact, the behavior of paying and the non-paying player is likely to be different. For future research, respondents need to be classified into paying and non-paying players.

\section{References}

[1] G. Kharisma, “The development of Indonesia's e-sports industry in 2019,” (in Bahasa). Techinasia, Jakarta, Aug. 03, 2019.

[2] W\&S Digital Marketing, "Mobile Games Trend in Indonesia 2017 Behavior of Mobile Games Usage," Jakarta, 2017. [Online]. Available: https://nusaresearch.com/upload/userfiles/files/MOBILE GAMES REPORT 2017(2).pdf.

[3] Octobryan, "Moba Still Unmoved? Let's take a look at the list of the 5 best mobile games for 2019," (in Bahasa). netz.id, 2019. https://netz.id/list/2019/12/11/00416/1003111219/moba-masih bergeming-yuk-intipdaftar-5-gim-mobile-terbaik-2019 (accessed Dec. 17, 2019).

[4] Indotelko, "Mobile Legends: Bang Bang played by 31 million people in Indonesia," (in Bahasa). Indotelko.com, 2019. https://www.indotelko.com/read/1571267366/mobilelegends-indonesia (accessed Dec. 17, 2019). 
[5] K. L. Hsiao and C. C. Chen, "What drives in-app purchase intention for mobile games? An examination of perceived values and loyalty," Electron. Commer. Res. Appl., vol. 16, pp. 18-29, 2016, doi: 10.1016/j.elerap.2016.01.001.

[6] K. L. Hsiao, "Android smartphone adoption and intention to pay for mobile internet:Perspectives from software, hardware, design, and value," Libr. Hi Tech, vol. 31, no. 2, pp. 216-235, 2013, doi: 10.1108/07378831311329022.

[7] R. Yulius, "Analysis of User Behavior in Purchasing Virtual Items in Online Games," (in Bahasa). J. Animat. Games Stud., vol. 3, no. 1, p. 1, 2017, doi: 10.24821/jags.v3i1.1582.

[8] G. N. Sweeney, J. C., \& Soutar, "Consumer Perceived Value: The Development of a Multiple Item Scale,” J. Retail., vol. 77, pp. 203-220, 2001, [Online]. Available: https://doi.org/10.1016/S0022-4359(01)00041-0.

[9] N. H. N. Asshidin, N. Abidin, and H. B. Borhan, "Perceived Quality and Emotional Value that Influence Consumer's Purchase Intention towards American and Local Products," Procedia Econ. Financ., vol. 35, no. October 2015, pp. 639-643, 2016, doi: 10.1016/s2212-5671(16)00078-2.

[10] D. Gursoy, E. R. Spangenberg, and D. G. Rutherford, "The Hedonic and Utilitarian Dimensions of Attendees' Attitudes Toward Festivals," J. Hosp. Tour. Res., vol. 30, no. 3, pp. 279-294, 2006, doi: 10.1177/1096348006287162.

[11] P. S. Wei and H. P. Lu, "Why do people play mobile social games? An examination of network externalities and of uses and gratifications," Internet Res., vol. 24, no. 3, pp. 313-331, 2014, doi: 10.1108/IntR-04-2013-0082.

[12] H. Chahal and N. Kumari, "Consumer perceived value: The development of a multiple item scale in hospitals in the Indian context," Int. J. Pharm. Healthc. Mark., vol. 6, no. 2, pp. 167-190, 2012, doi: 10.1108/17506121211243086.

[13] L. Zhao and Y. Lu, "Enhancing perceived interactivity through network externalities: An empirical study on micro-blogging service satisfaction and continuance intention," Decis. Support Syst., vol. 53, no. 4, pp. 825-834, 2012, doi: 10.1016/j.dss.2012.05.019.

[14] P. Kotler and G. Armstrong, Principles of Marketing, 17th ed. Harlow, UK: Pearson Education Limited, 2018.

[15] H. P. Lu and K. L. Hsiao, "The influence of extro/introversion on the intention to pay for social networking sites," Inf. Manag., vol. 47, no. 3, pp. 150-157, 2010, doi: 10.1016/j.im.2010.01.003.

[16] R. Bougie and U. Sekaran, Reseach Methods For Business: A Skill Building Approach, 8th ed. Hoboken, NJ: John Wiley \& Son, Inc., 2020.

[17] J. F. J. Hair, W. C. Black, B. J. Babin, and R. E. Anderson, Multivariate Data Analysis, 7th ed. Edinburgh Gate: Pearson Education Limited, 2014.

[18] Y. Yi and H. Jeon, "Effects of loyalty programs on value perception, program loyalty, and brand loyalty," J. Acad. Mark. Sci., vol. 31, no. 3, pp. 229-240, 2003, doi: 10.1177/0092070303031003002. 